УДК 371.13:811

\title{
БОГДАН КОЛОМІєЦЬ
}

Вищий державний навчальний заклад «Українська медична стоматологічна академія», м. Полтава

\section{ПЕДАГОГІЧНІ УМОВИ ФОРМУВАННЯ САМООСВІТНЬОЇ КОМПЕТЕНТНОСТІ МАЙБУТНЬОГО ВЧИТЕЛЯ ІНОЗЕМНОЇ МОВИ}

Потреба у формуванні самоосвітньої компетентності вимагає від сучасного викладача ЗВО навчити студента вчитися самостійно, здобувати знання впродовж усього життя. Мотив до проведення індивідуальної навчальної роботи потребує особливої уваги, тому цілі, що спонукають самоосвітян до навчання, представляють особливий інтерес для науковців. Контроль виконаної самоосвітньої роботи, також потребує особливої уваги викладача, оскільки представляє можливості оцінити якість ії проведення, мотивувати студентів, допомогає вирішити проблемні питання та $\epsilon$ тією умовою, яка забезпечує результативність індивідуального навчання.

Ключові слова: самоосвітня компетентність, самоосвіта, мотив, мотивація, навчання впродовж життя, самостійна робота, книга

Постановка проблеми. Сьогодення ставить перед сучасним викладачем завдання навчити студента вчитися, що забезпечить його успішну адаптацію в умовах світу де постійно зростає кількість інформації та змінюються вимоги до особи як до фахівця, за умови швидких темпів наукового та технічного прогресу. Ключем до ефективної самостійної навчальної роботи $є$ формування самоосвітньої компетентності, що зумовило потребу всестороннього дослідження поняття самоосвіта та самоосвітня компетентність.

Навчання впродовж життя оголошено стратегією розвитку вітчизняної освіти XXI ст., вирішенням цього завдання є своєчасне формування самоосвітньої компетентності.

Аналіз останніх досліджені та публікацій із проблеми. У педагогічному енциклопедичному словнику подано три основних підходи до тлумачення поняття «самоосвіта», а саме:

- як цілеспрямована, планова самостійна робота вчителя з метою підвищення власної професійної майстерності. Так «самоосвіта» постає, як професійна функція, метою якої є підвищення власної професійної майстерності;

- як процес цілеспрямованого та систематичного удосконалення, розвитку самого себе та своєї діяльності. У даному випадку, особистісний характер передбачає наявність процесу самопізнання;

- як вид, форма, засіб пізнавальної діяльності (Енциклопедія ...2008).

Мета статті - провести аналіз існуючих визначень та підходів до поняття самоосвіта та самоосвітня компетентність, за потреби доповнити його, встановити чинники впливу на процес формування самоосвітньої компетентності.

Виклад основного матеріалу. При визначенні поняття «самоосвіта» слід розглянути складові наведеного терміну, так «само» означає: «самостійно, без сторонньої допомоги». «Освіта» (вища) - це «сукупність систематизованих знань, умінь і практичних навичок, способів мислення, професійних, світоглядних і громадських якостей, морально-етичних цінностей, інших компетентностей, здобутих у ВНЗ у відповідній галузі знань за певною кваліфікацією на рівнях освіти, вищої ніж рівень повної загальної середньої освіти. Зважаючи на комплексність терміну, виникає необхідність детального і різностороннього дослідження феномену «самоосвіта».

Самоосвіта розглядаєтся спосіб пізнання себе та навколишнього світу шляхом передачі-отримання знань. Будь-яка ситуація в житті людини є частиною самоосвіти, направлена або випадкова дія на свідому поведінку людини. Цілковито погоджуємося з визначенням, але за відсутності систематизації пізнання та безструктурності, хаотичності виникаючих у житті ситуацій, а також без контролю такий вид освіти не буде ефективним.

Вчений Дзюбак Р.М. самоосвіту розглядає як - «здобуття знань на основі самостійних занять, без дозволу викладача» (Дзюбак, Гладка, 2010). Вважаємо наведене визначення занадто загальним, тому прийняли рішення деталізувати поняття самоосвіта.

«Самоосвіта» - це цілезумовлена самою особистістю систематична пізнавальна діяльність 3 метою розвитку освіченості (Громцева, 1987). Цілковито підтримуємо думку автора, але у цьому визначенні відсутні елементу контролю.

«Самоосвіта - це цілеспрямований процес самостійного оволодіння цілісною системою знань і умінь, поглядів і переконань, прогресивним досвідом у певній сфері діяльності під впливом особистих та суспільних інтересів» (Жукевич, 2011). Підтримуємо наведене автором твердження стосовно мотивів проведення індивідуальної навчальної роботи, на які впливають як власні цілі особистості так і вимоги суспільства та інше.

Наведені положення, дозволили виокремити ознаки самоосвіти; а саме:

- передбачає не лише закріплення професійних знань і засвоєння вже відомої наукової інформації, а має за мету отримання нової наукової, методичної інформації та практичних навичок; 
- має бути постійною;

- повинна позитивно сприяти оволодінню педагогом знаннями та їх застосуванням у практичній діяльності.

Самоосвіта не має чіткої структури ( $є$ варіативною, адже залежить від індивідуальних особливостей самоосвітянина) та направленості. Не існує двох однакових самоосвіт, оскільки з самого народження людина займається надзвичайно важливою справою - вона пізнає, тобто самоосвічується, спочатку під контролем сім'ї, потім вчителя, далі викладача.

Отже, процес самоосвіти в людини починається із самого народження. На основі отриманого досвіду пізнання, зважаючи на вплив родини та соціуму і формується особистість-самоосвітянин, це наштовхує на думку, що людина - «продукт (результат) самоосвіти». Самоосвіта - це потреба, що захищає особистість від інтелектуального зубожіння, це усвідомлений процес пізнавальної діяльності, удосконалення якостей людини або її навичок. Сенсом та метою «самоосвіти» $є$ постійний розвиток людини та їі становлення.

Зважаючи на велику кількість визначень поняття «самоосвіта», з різноманітних точок зору, слід вказати умови без яких вона неможлива:

- наявність друкованих видань, так як основним видом діяльності самоосвітянина є робота 3 книгою джерелом знань;

- уміння читати, для здобуття нової інформації, її опрацювання та перетворення на знання;

- наявність стійких внутрішніх мотивів до безперервного самостійного навчання.

Таким чином, у нашому дослідженні «самоосвіту» визначаємо як - безперервний процес постійного розвитку та становлення особистості майбутнього фахівця, що потребує спеціально організованого подальшого впливу та контролю якості її проведення разом з опосередкованим управлінням викладачем, шляхом направлення самоосвітнього інтересу та встановлення акцентів.

Завдяки отриманим тлумаченням терміну «самоосвіта», ми маємо можливість зазначити існування зв'язку, між поняттями «освіта» та «самоосвіта», зважаючи на їх спільний діяльнісний характер та мету. Відмінними є причини та результати проведення індивідуальної навчальної діяльності та її замовники.

Взаємозв'язок процесів «освіти» та «самоосвіти» зумовлений наступними чинниками: 1) сприяє накопиченню знань, формуванню інтелекту, розвитку розумових сил та здібностей; 2) $є$ інформативним процесом, складовою розумового самовиховання, завдяки якому виробляються якості для успішного оволодіння знаннями, уміннями, навичками. Також, спільною рисою $є$ пізнавальний характер індивідуальної навчальної діяльності.

Завдання формування самостійності студента - одна з головних проблем навчання, у той час як «самоосвітня діяльність» визначається верхівкою його розвитку, як суб'єкта навчально-пізнавальної діяльності, Саме тому визначаємо самостійність студента, складовою його самоосвітньої компетентності. С. Русова стверджувала: «На всяке навчання треба дивитись як на самонавчання...» (Гураш, 2001).

Причиною детального розгляду поняття «самоосвіта» та усіх його аспектів $\epsilon$ усвідомлення нами того, що суб'єктом соціального розвитку, та саморозвитку постає студент-самоосвітянин. Тому, якщо існують описані психологією механізми розвитку (саморозвитку) особистості, відповідно існують механізми впливу на нього. На прикладі студентів, вплив на самоосвіту здійснюють дорослі, батьки, ЗВО, група, які сукупно складають ситуативні фактори мотивації формування самоосвітньої компетентності майбутнього вчителя.

Додатково варто розглянути поняття самоосвітня компетентність, в контексті сім'ї, де особливого значення набуває приклад дорослих, моделі поведінки засвоюються в насідок некритичного сприйманнянаслідування з раннього віку. Результати проведення самостійної навчальної роботи оцінюються батьками, що формує позитивне або негативне до неї ставлення. В той час коли у ЗВО викладач логічно вибудовує організацію навчання. Одним з основних завдань постає навчання розумного використання часу студентами, які «...не тільки за дверима класу, часто і в самому класі вчаться марнувати час» (Бех, 2003).

Зважаючи на високий рівень впливу викладача на успішне формування самоосвітньої компетентності майбутнього вчителя іноземних мов, не слід забувати про роль групи, де в опосередкованій формі завжди існували й існують моделі ставлення до самостійної навчальної діяльності відповідно до пропаганди 3МІ, культури, суспільної думки, колективних настанов, етнопедагогічних стереотипів. Наприклад, при проведенні біографічного дослідження видатних особистостей, майже завжди, можливо знайти посилання на наполегливу самостійну роботу, вплив сім"ї є чи не найголовнішим. К. Ушинський зазначав що: «кращою спадщиною, яку може залишити своїй дитині бідний і багач - любов до праці» (Ушинський, 1983). Таким чином, ми маємо можливість додати оточення самоосвітянина до складових комплексу «самоосвітня компетентність» майбутнього вчителя.

Позапрограмність «самоосвіти» визначає позааудиторні форми та види проведення занять, що сприяють виникненню бажання до проведення самостійної пізнавальної діяльності. Спонукають до самоосвітньої діяльності й заходи загальнокультурного розвитку студентів, а саме: відвідування виставок, театрів, зустрічі з цікавими людьми тощо. Мотив визначає мету, у той час як мета програмує діяльність щодо ії досягнення. Із досліджень науковців бачимо, що чим більша кількість мотивів визначає мету, тим більшою є її спонукальна сила. Зважаючи на це, завдання викладача ЗВО - примножувати мотиви для формування самоосвітньої компетентності майбутніх учителів іноземних мов, використовуючи позапрограмні матеріали, форми проведення занять, заходи для культурного розвитку студентства та їх власну мету навчатися. 
Згідно з думкою Н. Коваленко (2009), «самоосвітня компетентність - є складною інтегрованою властивістю особистості, що забезпечує готовність задоволення індивідуальної та соціальної потреби пізнання нею дійсності на основі оволодіння знаннями, уміннями та навичками, способами діяльності та набутого досвіду продуктивно здійснювати самостійне систематичне цільове освоєння соціального досвіду людства. Це готовність і здатність особистості до самостійного, систематичного, цілеспрямованого пізнання дійсності, освоєння соціального досвіду людства, самореалізації, саморозвитку. Це інтегрована якість особистості, яка грунтується на уміннях самоосвітньої діяльності та визначає готовність особистості до самоосвіти, самонавчання, самовдосконалення, самовибору, самореалізації упродовж життя 3 усвідомленням особистих і суспільних потреб. Це готовність і здатність особистості до самоосвітнього розвитку, самостійного творення себе». Ми погоджуємося з досить розгорнутим визначенням самоосвіти та пропонуємо доповнити його твердженням, що процес самостійного здобуття знань має бути систематизований професіоналами та контролюватися і направлятися викладачами.

Наступною складовою комплексу «самоосвітня компетентність» майбутніх вчителів, ми називаємо постійне позитивне емоційне підкріплення (оцінка, похвала), яка принесе задоволення від результатів додаткової роботи студентові внаслідок чого активізує роботу з формування самоосвітньої компетентності. Позитивна мотивація до проведення самостійного здобуття знань має підкріплюватися почуттям задоволеності, радості.

I. Бех стверджував, що: «серед усього розмаїття людських емоцій саме почуття радості має величезний виховний потенціал, воно збільшує здатність індивіда пізнати й оцінити світ та виступає психологічним механізмом розвитку схильностей» (Бех, 2003). Таким чином, ми визначили позитивне емоційне підкріплення самоосвітньої діяльності однією з потенційно потужних сил мотивації студентів, які виконують індивідуальну навчальну роботу.

Так як предметом самоосвітньої компетентності постає інформація, важливо правильно визначити підходи для оволодіння нею. У процесі навчання в стінах 3В0, залученням до самостійної роботи займається педагогічний колектив, на противагу самоосвітній навчальній діяльності, де самостійна робота студентів вимагає контролю її якості та пояснення проблемних питань викладачем.

Враховуючи твердження В.А. Сухомлинського, що: «основним видом діяльності в процесі самоосвіти $\epsilon$ робота з книгою», визначаємо читання - як основу самоосвіти. Самоосвіта складається з повного розуміння предмету, тому необхідно вивчати матеріал наочно, оскільки самоосвіта майбутнього вчителя буде базуватись на самодіяльності за допомогою наочного пізнання; під час самоосвітньої діяльності слід рухатись від простого до складного, від відомого до невідомого. Варто зазначити, що «самоосвіта» - процес, що потребує не тільки затрат часу, а й матеріальних витрат, адже опановувати невідоме можливо лише за умови наявності відповідної книги. Як зазначав В.А. Сухомлинський, «самоосвіта» є: «системним явищем і являє собою повне оволодіння певними знаннями, системну діяльність, що спрямована на засвоєння накопичених цінностей культури; особливий вид людської діяльності з метою отримання знань для формування власної особистості; поєднання знань з якостями особистості та формування її інтелектуальної культури» (Сухомлинський, 1987). Ми погоджуємося з видатним українським педагогом та вважаємо, що книга може бути джерелом інформації не тільки в друкованому вигляді, а й у цифровому.

Предметом «самоосвіти» у 3ВО постають інформаційні матеріали, які виходять за межі навчальної програми, передбачають опрацювання додаткової літератури 3 метою набуття навичок організації самостійної пізнавальної діяльності. Тому завданням викладача є навчити самоосвітян:

1) основним правилам культури роботи з інформаційним матеріалом;

2) прийомам культури читання та слухання, методиці здійснення виписок, різновидів цитування, бібліографії;

3) особливостям викладу власних думок у різних стилях;

4) прийомам запам'ятовування та зосередження уваги;

5) прийомам раціональної організації часу, розумного чергування праці й відпочинку.

Висновки і перспективи подальших розвідок. Нам вдалося проаналізувати достатню кількість визначень науковців терміну самоосвіта та виокремити не тільки спільне, але й відсутнє в них, а саме те, що науковці оминають тему контролю самоосвіти. Починаючи з тверджень, що самоосвіта - це повсякденне життя або навчання у ЗВ0, науковці не визначають контроль самоосвіти як проблему. На нашу думку саме оцінка проведення індивідуальної навчальної роботи має один з найбільших мотиваційних чинників до їі проведення. Оскільки позитивна оцінка роботи тими, чию думку студент-самоосвітянин цінує, $\epsilon$ підтвердженням правильності проведеної діяльності та стимулює його до її продовження. Форми контролю індивідуальної навчальної роботи потребують особливої уваги та подальшого дослідження. Ми стверджуємо, що самоосвітня діяльність вимагає оцінювання та контролю.

\section{Список використаних джерел}

Бех, І. Д. (2003). Виховання особистості: у 2-х кн. Київ: Либідь. - Кн. 2. Особистісно-орієнтований підхід: науково-практичні засади.

В. А. Сухомлинский: Библиография (1987) Сост. А. И. Сухомлинская, О. В. Сухомлинская. Киев: Рад. Школа.

Громцева, А. К. (1987). Самообразование учащихся средних профтехучилищ. Шапкин, В.В. (Отв. ред.). Москва: Высшая школа.

Гураш, Л. (2001). Софія Русова - «апостол Правди і Науки». Дошкільне виховання, 2, 10-11. 
Дзюбак, Р.М., Гладка, Н.М. (2010). Організачійно-методична діяльність методичного кабінету щодо створення умов для розвитку педагогічної ініціативи. Самоосвіта педагогічних працівників. Посібник. Черкаси.

Еничиклопедія освіти (2008). Кремень, В. Г. (Гол. ред..), Акад. пед. наук України. Київ: Юрінком Інтер

Жукевич, І. П. (2011). Поняття самоосвіти студентів у контексті неперервної освіти. Вісник Житомирського державного університету. Педагогічні науки. - Житомир:ЖДУ, Випуск 60, 116 - 119.

Коваленко, Н. В. (2009). Формування самоосвітньої компетениії учнів основної школи сільської місиевості: (Дис. канд. пед. наук: 13.00.09). Суми.

Ушинський, К. Д. (1983). Вибрані педагогічні твори: В 2 т. Київ, Т. І, (105-108, 113, 116-120).

\section{References}

Bekh I. D. Vykhovannia osobystosti: u 2-kh kn. / I. D. Bekh. - K.: Lybid, 2003. - Kn. 2. Osobystisno-oriientovanyi pidkhid: naukovo-praktychni zasady. $-344 \mathrm{~s}$.

V. A. Suhomlinskiy: Bibliografiya (1987) Sost. A. I. Suhomlinskaya, O. V. Suhomlinskaya. Kiev: Rad. Shkola.

Gromtseva, A. K. (1987). Samoobrazovanie uchaschihsya srednih proftehuchilisch. Shapkin, V.V. (Otv. red.). Moskva: Vyisshaya shkola.

Hurash, L. (2001). Sofiia Rusova - «apostol Pravdy i Nauky». Doshkilne vykhovannia, 2, 10-11.

Dziubak, R.M., Hladka, N.M. (2010). Orhanizatsiino-metodychna diialnist metodychnoho kabinetu shchodo stvorennia umov dlia rozvytku pedahohichnoi initsiatyvy. Samoosvita pedahohichnykh pratsivnykiv. Posibnyk. Cherkasy.

Entsyklopediia osvity (2008). Kremen, V. H. (Hol. red..), Akad. ped. nauk Ukrainy. Kyiv: Yurinkom Inter

Zhukevych, I. P. (2011). Poniattia samoosvity studentiv u konteksti neperervnoi osvity. Visnyk Zhytomyrskoho derzhavnoho universytetu. Pedahohichni nauky. - Zhytomyr:ZhDU, Vypusk 60, 116 - 119.

Kovalenko, N. V. (2009). Formuvannia samoosvitnoi kompetentsii uchniv osnovnoi shkoly silskoi mistsevosti: (Dys. kand. ped. nauk: 13.00.09). Sumy.

Ushynskyi, K. D. (1983). Vybrani pedahohichni tvory: V 2 t. Kyiv, T. I,. (105-108, 113, 116-120).

\section{KOLOMIIETS B.}

Ukrainian medical Stomatological academy Poltava, Ukraine

\section{PEDAGOGICAL CONDITIONS OF SELF-COMPETENCE FORMATION FOR FUTURE TEACHERS OF FOREIGN LANGUAGES}

It is required to help the students to acquire self-competence from teachers. To learn to study is necessary to feel confident in modern world due to the rate of changes occurring in every branch of human life. The ability to self-learning is one of the essential for those students who want to address the needs of time. Every moment brings new techniques or approaches in our life in general and in professional life in particular, thus once you acquired the diploma and passed the exams, which confirm your level of understanding corresponding issues, you become a specialist not for all remaining life but only for a short period of time. It is caused by growing information amount on every topic and this process demands constant learning. The self-education reacquires not only the efforts from the student to comprehend the material but also the control from professor to check if those actions were effective. Motive and motivation are also of great importance because it is the student who decides to provide individual learning under influence of family, his own feelings or other issue and his needs and aims makes him to learn more or less effective. There are so many definitions for self-education in the scientific literature so we can mark the peculiarities of it and find the essence of this notion to provide better understanding of this phenomenon and clarify the idea. Nevertheless, much of them do not put the element of control in their determinations when we claim that it is essential and integral part of the self-learning. To win approval from the family or from University staff will provide the student with the assurance of effectiveness of his individual study efforts. The influence on personal motivation from academic group members or from family is undoubted as it begins from early childhood when and such behavior patterns stays for all future life.

Key words: self-learning, motive, motivation, elements of control, self-education, constant learning

Стаття надійшла до редакції 12.10.2018 р. 